\title{
PREPOSISI DALAM BAHASA KAILI
}

\section{PREPOSITIONS IN KAILI LANGUAGE}

\author{
Tamrin \\ Balai Bahasa Provinsi Sulawesi Tengah \\ Jalan Untad I, Bumi Roviga, Tondo, Palu 94118 \\ Telepon (0451) 4705498; 421874 / HP. 085240066115 \\ Faksimile (0451) 421843; e-mail: thamrin21@ymail.com
}

\begin{abstract}
Kaili language is the language spoken in Central Sulawesi. As the native language, Kaili language plays an important role in the society. Therefore, as a local language, Kaili language needs to be maintained and preserved. This research aimed at (1) describing and determining the forms of preposition in Kaili language and (2) describing the function of prepositions in the sentence. Interview was done as the method of the research. The results show that there are two forms of prepositions in Kaili Language. They are single preposition and combined preposition. Single preposition consists of root word and prefix preposition while combined preposition consists of adjoining preposition, correlated preposition, and locative nominal preposition. Prepositions in Kaili language may function as place marker, causative marker, manner marker, time marker, purposive marker, and comparative marker.
\end{abstract}

Keywords: language, preposition, Kaili language

\begin{abstract}
Abstrak
Bahasa Kaili adalah bahasa yang digunakan di Sulawesi Tengah. Sebagai bahasa daerah, bahasa Kaili memegang peranan penting dalam kehidupan masyarakat Kaili. Oleh karena itu, bahasa Kaili sebagai bahasa daerah, perlu dipelihara dan dilestarikan. Berdasarkan hal tersebut penelitian ini bertujuan untuk (1) mendeskripsikan dan mengetahui bentuk preposisi dalam bahasa Kaili dan (2) mendeskripsikan fungsi preposisi dalam sebuah kalimat dalam bahasa Kaili. Metode yang digunakan adalah metode cakap dengan teknik dasar yaitu teknik pancing dan teknik lanjutan yaitu teknik cakap semuka. Hasil analisis menunjukkan bahwa bentuk preposisi dalam bahasa Kaili terdiri atas dua macam, yaitu preposisi tunggal dan preposisi gabungan. Preposisi tunggal terdiri atas preposisi berupa kata dasar dan preposisi yang berprefiks. Preposisi gabungan terdiri atas preposisi yang berdampingan, preposisi yang berkorelasi, dan preposisi nomina lokatif. Fungsi preposisi dalam bahasa Kaili yaitu sebagai penanda hubungan tempat, penanda hubungan maksud, penanda hubungan cara atau alat, penanda hubungan waktu, penanda hubungan sebab, penanda hubungan tujuan, dan penanda hubungan perbandingan.
\end{abstract}

Kata kunci: bahasa, preposisi, bahasa Kaili 


\section{Pendahuluan}

Bahasa adalah sistem lambang bunyi yang arbitrer yang digunakan oleh para anggota kelompok sosial untuk bekerja sama, berkomunikasi, dan mengidentifikasikan diri. Demikian juga bahasaKaili, selanjutnya disingkat BK. BK adalah salah satu bahasa daerah di Sulawesi Tengahyang masih dipelihara oleh masyarakat suku Kaili sebagai lambang identitas suku bangsa tersebut dan dipelihara sebagai alat komunikasi lisan antarkeluarga. Di samping itu, juga masih dipakai sebagai bahasa pengantar di kelaskelas terendah sekolah dasar di Kabupaten Donggala, Kabupaten Sigi, dan KabupatenParigi Moutong terutama di wilayah pedesaan.

Bahasa Kaili tumbuh dan berkembang dalam masyarakat suku Kaili dan merupakan pencerminan kebudayaan daerah itu sendiri, sehingga dengan menggunakan bahasa tersebut akan mendukung dan memperkaya khazanah kebudayaan Indonesia. Penggunaan BK dalam kegiatan sehari-hari adalah sesuatu yang wajar dilakukan oleh pemakainya dalam kehidupan bermasyarakat, seperti yang dikemukakan oleh Samsuri (1985: 3) bahwa bahasa wajar dimiliki oleh setiap manusia, dan kewajaranitu mungkin menyebabkan bahasa dianggap sebagai barang sehari-hari yang biasa saja, sehingga tidak perlu mendapat perhatian yang banyak sesuai dengan fungsinya dalam masyarakat.

Aspek kebahasaan BK belum seluruhnya terjamah oleh para peneliti, diantaranya adalah preposisi BK.Dari serangkaian penelitian BK selama ini, pada dasarnya preposisi telah dibicarakan melalui contohcontoh pemakaian bahasa terutama dalam Kata Tugas BK, Struktur BK dan Tata Bahasa Kaili. Namun, secara khusus dan terperinci belum pernah diadakan penelitian terhadap Preposisi BK. Tarigan (1984: 50) mengatakan istilah preposisi digunakan untuk mengacu pada sebuah kategori kata yang terletak di depan kategori lain, terutama nomina, untuk membentuk frase preposisi. Preposisi dalam sebuah kalimat tidak memiliki arti tanpa kehadiran kata dari kategori lain sebagai pelengkapnya. Misalnya: Saya di rumah.Kalimat Saya di rumah tidak memiliki makna yang komunikatif sebagai kalimat tanpa dibubuhi preposisi $d i$.

Gramatika, Volume II, Nomor 1, Januari-Juni 2014
Memperhatikan kenyataan tersebut jelas bahwa penelitian tentang preposisi dalam BK perlu dilaksanakan guna memperoleh data dan informasi yang lengkap tentang BK. Hal tersebut dilakukan untuk membina, memelihara, dan menyelamatkan bahasabahasa daerah yang jumlah penuturnya sangat terbatas, bukan hanya menjadi kepentingan masyarakat peneliti, melainkan juga menjadi kepentingan nasional.

Menurut Kaseng (1979: 9) BK memiliki dua belas dialek, yaitu (1) Ledo, (2) Rai, (3) Tajio, (4) Kori, (5) Unde, (6) Doi, (7) Da'a , (8) Ija, (9) Uma, (10) Ado, (11) Ava, dan (12) Tara. Dari dialek-dialek tersebut, dialek Ledo memiliki jumlah penutur terbesar dan mendiami daerah ibukota Provinsi Sulawesi Tengah. Oleh karena itu, dialek tersebut menjadi lingua franca antarpenutur dilaek lain. Dengan alasan itulah penulis membatasi dirihanya pada bahasa Kaili dilaek Ledo.

Permasalahan yang ingin dijawab dalam penelitian ini adalah (1) Bagaimanakah bentuk preposisi dalam BK? dan (2) Bagaimanakah fungsi preposisi tersebut dalam sebuah kalimat? Tujuan penelitian ini adalah (1) mendeskripsikan bentuk preposisi dalam BK dan (2) mendeskripsikan fungsi preposisi dalam BK.

Secara teoretis penelitian ini dapat bermanfaat untuk menambah pengetahuan dan wawasan peneliti tentang penggunaan preposisi dalam kalimat BK. Selain itu, menjadi sumber masukan bagi peneliti lain dalam mengkaji lebih lanjut mengenai preposisi dalam BK.

Secara praktis, penelitian ini dapat memperkenalkan BK kepada masyarakat sebagai salah satu bahasa daerah yang dapat memperkaya kebudayaan nasional. Selain itu, sebagai informasi bagipemerintah daerah mengenai hasil penelitian baru tentang BK. Usaha ini diharapkan pula sebagai pelestarian, pembinaan, dan pengembangan salah satu bahasa nusantara, yaitu BK di Kota Palu Provinsi Sulawesi Tengah.

\section{Kerangka Teori}

Setiap bahasa memiliki kata depan atau preposisi. Preposisi adalah kata yang biasa terdapat di depan nomina, misalnya: dari, dengan, di dan ke (Alwi, 2005: 894). 
Menurut Chaer (1994: 154), preposisi adalah kata-kata yang digunakan di depan kata benda untuk merangkaikan nomina itu dengan bagian kalimat lain. Menurut Pedoman Umum Ejaan Bahasa Indonesia yang Disempurnakan (2007:24), preposisi $d i$, ke, dan dari ditulis terpisah dari kata yang mengikutinya kecuali di dalam gabungan kata yang sudah lazim dianggap sebagai satu kata seperti kepada dan daripada.

Alwi (2003: 288) mengatakan preposisi menandai berbagai hubungan makna antara konstituen di depan preposisi tersebut dengan konstituen di belakangnya. Preposisi di menyatakan tempat, misalnya di rumah, di toko, di Medan, dan sebagainya. Jadi, sebagai preposisi, di ditulis terpisah dari unsur yang menyertainya. Preposisi pada juga ditulis terpisah dari unsur yang menyertainya, misalnya: pada saat, pada tahun, pada hari Minggu, dan sebagainya. Sebagai preposisi, ke juga menyatakan tempat, seperti kata depan di. Akan tetapi, tempat yang dinyatakan oleh preposisi ke bukan tempat yang (telah) dituju melainkan tempat yang (akan) dituju, misalnya: ke dalam, ke luar, ke rumah (Ritonga 2008: 67).

Preposisi dalam sebuah kalimat tidak memiliki arti tanpa kehadiran kata dari kategori lain sebagai pelengkapnya. Misalnya: Saya di rumah. Berdasarkan contoh tersebut, kata di tidak akan memiliki arti apabila tidak disertai kata dari kategori lain yaitu rumah. Jadi, preposisi tidak memiliki makna leksikal tetapi memiliki makna gramatikal, yaitu makna yang ditimbulkan akibat adanya hubungan antara kata yang satu dengan kata yang lain dalam sebuah kalimat. Oleh karena itu, preposisi tidak memiliki makna bebas yang dapat berdiri sendiri. Begitu pentingnya preposisi dalam sebuah kalimat, dapat ditunjukkan dalam contoh : Saya di rumah. Apabila preposisi $d i$ dihilangkan, maka kalimat tersebut menjadi Saya rumah. Kalimat tersebut tidak gramatikal dan tidak memiliki arti. Jadi, preposisi dalam sebuah kalimat sangat penting.

Teoriyang digunakan dalam penelitian ini adalah teori yang dikemukakan oleh Tarigan (1984: 50) yang mengatakan bahwa preposisi digunakan untuk mengacu pada sebuah kategori kata yang terletak di depan kategori lain, terutama nomina, untuk membentuk frase preposisi. Selain itu, dalamhal analisis fungsi preposisi dalamkalimat, penelitian ini didukung juga oleh teori tentang preposisi yang dikemukakan oleh Alwi dalam buku Tata Bahasa Baku Bahasa Indonesia.

\section{Metode}

Penelitian ini termasuk jenis penelitian lapangan dengan pendekatan linguistik struktural. Kehadiran teori linguistik struktural dalam analisis satuan-satuan linguistik suatu bahasa menghasilkan berbagai pandangan dengan pendukungnya masing-masing. Di dalam melakukan penelitian ini pandangan itu diterapkan secara eklitik yakni prinsip dan konsep yang relevan dan berguna dalam analisis preposisi khususnya, dan morfologipada umumnya.

Jenis data yang diambil berupa data kualitatif. Data kualitatif diperoleh dengan menggunakan metode cakap dan metode simak, yakni peneliti melakukan wawancara dengan para informan secara terstruktur yang telah ditetapkan dan sekaligus menyimak tuturan para informan tersebut (Sudaryanto, 1993:133).

Dalam pelaksanaannya, metode cakap dilakukan dengan teknik pancing, sedangkan metode simak dilakukan dengan teknik sadap. Untuk kelancaran pelaksanaannya, peneliti telah mempersiapkan instrumen berupa daftar pertanyaan yang telah disusun berdasarkan kebutuhan penelitian preposisi yang diperkirakan terdapat dalam BK.

Selanjutnya, digunakan teknik rekam yang dilakukan tanpa sepengetahuan penutur sumber data atau pembicara dan teknik catat yakni mencatat tuturan para informan. Data yang diperoleh diklasifikasikan ke dalam kelompok tertentu dan dipilih sesuai dengan kriteria yang telah ditetapkan.

Data yang diperoleh berasal dari dua sumber, yakni (1) data lisan sebagai data utama, dan (2) data tertulis sebagai data penunjang. Data lisan ditetapkan sebagai data primer karena BK merupakan bahasa lisan atau bahasa yang berupa tuturan sehingga data tertulis yang memadai sukar diperoleh. Data lisan yang diperoleh berupa tuturan $\mathrm{BK}$ yang digunakan oleh para penuturnya dalam komunikasi sehari-hari di rumah dan dalam lingkungan masyarakat, sedangkan data tertulis berupa hasil penelitian yang berhubungan 
dengan BK dan cerita rakyat yang telah didokumentasikan.

\section{Pembahasan}

Jika ditinjau dari dari segi bentuknya, preposisi ada tiga macam, yaitu preposisi tunggal, preposisi gabungan, dan preposisi nomina lokatif.

\section{a. Preposisi Tunggal}

Preposisi tunggal ialah preposisi yang hanya terdiri atas satu kata. Bentuk preposisi tunggal tersebut berupa kata dasar dan kata berafiks. Preposisi tunggal yang berupa kata dasar seperti $r i$ 'di', $k a$ 'untuk', aga 'kecuali', dan bentuk ulang seperti lenje-lenjena 'ruparpanya', nemo-nemo 'jangan-jangan', dan nenggilanggila 'mengkilat-kilat'. Preposisi kata berafiks dibentuk dengan menambahkan afiks (imbuhan) pada bentuk dasar, seperti verba, adjektiva, atau nomina. Berikut adalahuraiannya.

\section{Preposisi Berupa Kata Dasar}

Preposisi yang berupa kata dasar ialah preposisi yang hanya terdiriatas satu morfem, karena itu tidak dapat diperkecil lagi. Berikut ini adalah contohnya.

1. I Fatinah hilau ri kantoro de pangade padondo. 'Si Fatinah pergi ke kantor sejak tadi pagi.'

(Fatinah pergi ke kantor sejak tadi pagi.)

Preposisi ri dalam bahasa Kaili sama dengan preposisi 'ke'dalam bahasa Indonesia yang menyatakan tempat yang dituju dari perbuatan atau tindakan yang dilakukan. Preposisi ini diletakkan di sebelah kiri nomina danmenandai hubungan arah menuju suatu tempat. Preposisi $r i$ dapat diikuti kata yang menyatakan bagian mana dari tempat yang dituju seperti contoh pada nomor 1 tersebut.

2. I Asri nonturo ri bavo motoro.

'Si Asri duduk di atas motor.'

(Asri duduk di atas motor.)

Preposisi $r i$ 'di' digunakan juga untuk menyatakan tempat berada. Untuk menyatakan tempat berada secara terperinci preposisi $r i$ 'di' bisa diikuti oleh kata yang menyatakan bagian dari tempat itu.

3. I Fery noasala dako ri Papua.

'Si Fery berasal dari di Papua.'

(Fery berasal dari Papua.)
Preposisi dako 'dari' merupakan preposisi yang menyatakan tempat berasal nomina yang mengikutinya. Preposisi ini diletakkan di sebelah kiri nomina yang menyatakan tempat.

4. I Sulkifli hilau ante roana.

'Si Sulkifli pergi dengan temannya.'

(Sulkifli pergi bersama dengan temannya.)

Preposisi ante 'dan/ dengan' merupakan preposisi yang menyatakan alat untuk atau dalam melakukan perbuatan atau tindakan yang dinyatakan oleh predikat klausa yang bersangkutan.

\section{Banua mbaso haitu niali ante I Aminah.}

'Rumah besar itu dibeli oleh si Aminah.'

(Rumah yang besar itu dibeli oleh Aminah.)

Preposisi ante ‘oleh' adalah preposisi yang menyatakan pelaku perbuatan atau tindakan yang disebutkan dalam predikat klausa. Preposisi ini terletakdi sebelah kiri nomina yang menyatakan orang atau yang diorangkan.

6. I Sumarni da nakodi naboli nosinggani manggena.

'Si Sumarni sejak kecil tinggal bersama pamannya.'

(Sumarni sejak kecil tinggal bersama dengan pamannya.)

Preposisi $d a$ 'sejak/semenjak' merupakan preposisi asal waktu, dalam BK secara umum dapat digunakan untuk menggantikan preposisi asal waktu dako. Preposisi tersebut merupakan ungkapan yang menerangkan tentang lamanya waktu.

7. Dako ruru sampe nggapuri ledo nabali sipana.

'Dari dulu hingga sekarang tidak berubah sifatnya.'

(Dari dulu hingga sekarang sifatnya tidak berubah.)

8. Da mpadondo sampe nakava naeo tona haitu nobalu ri gade.

'Dari pagi sampai datang siang orang itu menjual di pasar.'

(Dari pagi sampai siang orang itu berjualan di pasar.)

Preposisi tempat tertentu sampe 'sampai', hingga' adalah preposisi yang menyatakan awal tempat kejadian hingga akhir tempat kejadian. Preposisi tersebut berupa preposisi $d a$ 'dari' yang disertai dengan preposisi sampe 'sampai'. 
9. Bau hi kai guru.

'Ikan ini untuk si guru'.

Ikan ini untuk Pak Guru

Preposisi $k a$ 'untuk' merupakan preposisi yang berfungsi menandai hubungan peruntukan.

10. Razak ledo nosokolah apa tinana namate.

'Razak tidak sekolah karena ibunya mati.'

(Razak tidak ke sekolah karena ibunya meningal dunia.)

11. Ngana hai negelo-ngelo saba novia posijaguru.

'Anak itu mencari-cari sebab perkelahian.'

(Anak itu mencari-cari sebab perkelahian.)

Preposisi apa 'karena, dan saba 'sebab'dalam BK, merupakan preposisi yang menandai hubungan sebab.

\section{Preposisi yang Berprefiks}

Preposisi berprefiks dalam BK adalah preposisi yang terdiri dari bentuk dasar dan afiks. Afiks yang melekat pada preposisi polimorfemis berupa prefiks. Bentuk dasar yang dilekatinya adalah sagulili 'sekeliling', nosinggani 'bersama', risinjori 'sekitar', dan rikandate 'sepanjang'. Bentuk kata sagulili berasal dari kata dasar gulili 'keliling' nosinggani berasal dari kata dasar singgani 'sama' risinjori berasal dari kata dasar sinjori 'kitar' dan kata rikandate berasal dari kata dasar kandate 'panjang'.

Berikut adalah contohnya dalam kalimat.

12. Sagulili kantoro nituda nu gampaya.

'Sekeliling kantor ditanam pepaya.'

(Sekeliling kantor ditanami pohon pepaya.)

13. I toma hilau nosinggani ina riavi nggovia.

'Si ayah bersama ibu pergi kemarin sore.'

(Ayah pergi bersama ibu kemarin sore.)

14. Ri sinjori banuaku nadea kaluku.

'Sekitar rumahku banyak kelapa.'

(Sekitar rumahku banyak pohon kelapa.)

15. Rikandatedala naroa tona nobalu-balu.

'Sepanjang jalan ramai orang berjual-jualan.' (Sepanjang jalan ramai orang berjualan.)

16. Ane eva, iko ledo nasala yaku mabia mbasalikumu.

'Andaikata, kamu tidak salah saya berani membelamu.'
(Andaikata, engkau tidak bersalah, maka saya akan membelamu.)

\section{b. Preposisi Gabungan}

Preposisi gabungan dalam BK terdiri atas (1) preposisi yang berdampingan (2) preposisi yang berkorelasi dan (3) preposisi nomina lokatif.

\section{Preposisi yang Berdampingan}

Preposisi yang berdampingan dalam BK adalah preposisi yang terdiri atas dua preposisi yang letaknya berdampingan. Preposisi itu dalam BK-adalah sampe ante 'sampai dengan', sampe ri 'sampai di', ntanina dako'selain dari', dan nibasaka dako 'lepas dari'. Berikut ini adalah contoh dalam kalimat.

17. Kami nolipa sampe ri bulu.

'Kami berjalan sampai di bukit.'

(Kami berjalan sampai ke bukit).

18. I Sudirman niolina soal lamoro sangu sampe ante lamoro sapulu.

'Si Sudirman menjawab soal nomor satu sampai dengan nomor sepuluh'.

(Sudirman menjawab soal nomor satu sampai dengan nomor sepuluh).

19. Ntanina dako tuakana ia muni nete pelasi.

'Selain dari kakaknya ia juga terpilih.'

(Selain dari kakaknya ia juga terpilih.)

20. Manu haitu nibasaka dako ripale.

'Ayam itu lepas dari tangannya.'

(Ayam itu lepas dari tangannya.)

21. Ntanina dako I mange tidak ada orang yang menolongmu.

'Selain dari si paman tidak ada orang yang menolongmu.'

(Selain dari paman tidak ada orang yang menolongmu.)

\section{Preposisi yang Berkorelasi}

Preposisi yang berkorelasi dalam BK adalah gabungan preposisi yang terdiri atas dua unsur yang dipakai berpasangan, tetapi terpisah oleh kata atau frasa yang lain. Berikut adalah contoh preposisi yang berkorelasi.

22. Riantara kota Palu ante kota Makasar bagi yaku naria niposanaku mboto.

'Diantara kota Palu dengan kota Makassar bagi saya ada kenangan tersendiri.' 
(Antara kota Palu dengankota Makassar bagiku ada kenangan tersendiri.)

23. Yaku ledo nokaraja vai ri PT Cussons daa mpae ruru sampe nggapuri.

'Saya tidak bekerja lagi di PT Cussons sejak setahun lalu sampai sekarang.'

(Saya tidak bekerja lagi di PT Cussons sejak setahun yang lalu hingga sekarang).

24. Riantara yaku ante radaa haitu aga no roa. 'Diantara saya dengan gadis itu sebatas teman.' (Antara saya dengan gadis itu hanya sebatas teman.)

25. Ngana haitu notumangi dako Tondo sampe ri Roviga.

'Anak itu menangis dari Tondo sampai di Roviga.'

(Anak itu terus menangis dari Tondo sampai ke Roviga.)

26. Randaa haitu nolipa dako kampus hilau ri banuana.

'Gadis itu berjalan dari kampus sampai ke rumahnya.'

(Gadis itu berjalan dari kampus ke rumahnya).

27. Dako nggaulu sampe nggapuru, tinaku da najadi katua PKK.

'Sejak dulu sampai sekarang, ibuku masih menjadi ketua PKK.'

(Sejak dulu hingga sekarang, ibuku masih menjadi ketua PKK.)

28. Dako ponika sampe naria ngana saito, kami ledo nobanua mboto.

'Darimenikah sampai punya anak satu, kami tidak berumah sendiri.'

(Sejak menikah sampai dengan punya anak satu, kami tidak berumah sendiri.)

29. I mangge no kantoro dako padondona sampai nggoviana.

'Paman berkantor dari pagi sampai sore.'

\section{c. Preposisi dan Nomina Lokatif}

Dalam BK, suatu preposisi juga dapat bergabung dengan dua nomina asalkan nomina yang pertama mempunyai ciri lokatif. Dengan demikian, ditemukan frasa preposisional, seperti ri ara nulamari 'di atas lemari', ri bavo numeja 'di atas meja', ri aranuruanga 'ke dalam ruangan', dako niara nupeti 'dari dalam peti'. Struktur frasa preposisional ini dapat dilihat pada bagan berikut.

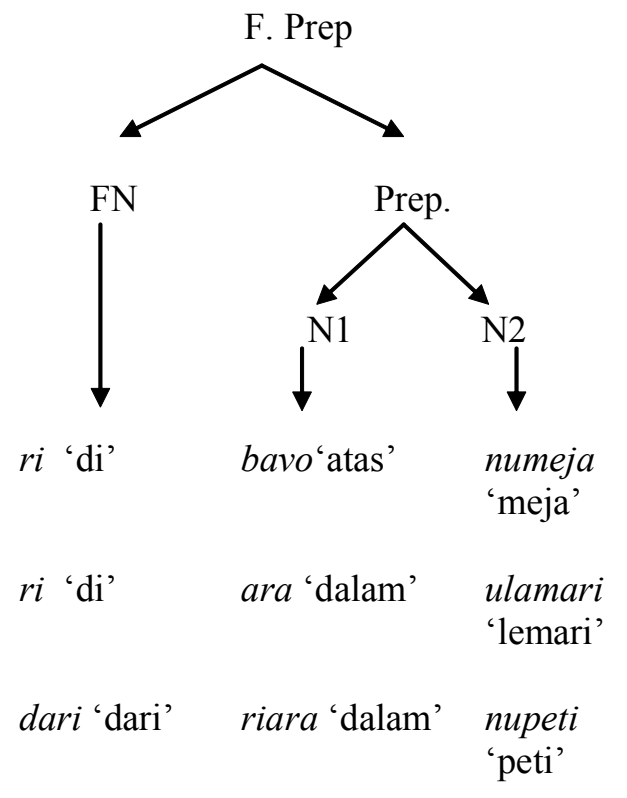

Dari diagram di atas tampak bahwa bavo 'atas', ara 'dalam', dan dari 'dari' merupakan bagian dari frasa nominal bavo numeja 'atas meja', ara nulamari 'dalam lemari', dan ara nupeti 'dalam peti'. Sebagian dari kelompok N1 maupun N2 ada yang wajib muncul dan ada pula yang mana suka. Kelompok N1 yang tidak wajib muncul adalah misalnya bavo 'atas' dan ara 'dalam'. Muncul tidaknya N1 itu dipengaruhi oleh ciri semantik N2 yang dimensinya berbeda-beda. Karena numeja 'meja', misalnya mempunyai dimensi dua (panjang dan lebar), maka I meja 'di meja' diartikan sama dengan i bavo numeja 'di atas meja'. Berikut adalah contohnya dalam kalimat.

30. Bolika pingga haitu ri bavo numeja.

'Simpan piring itu di atas meja.'

(Letakkan piring itu di atas meja.)

31. Popompene kadera haitu ri bavo nu oto trek.

'Kasi naik kursi itu ke atas mobil trek.'

(Naikkan kursi itu ke atas mobil trek.)

32. Tona haitu nipopanau dako ri bavo nukapala.

'Orang itu diturunkan dari atas kapal.'

(Orang itu diturunkan dari atas kapal.)

33. Pakaea haitu naria ri ara nulamari.

'Pakaian itu ada di dalam lemari.'

(Pakaian itu ada di dalam lemari.) 
34. Bara haitu nisuaraka ri ara nuruanga. 'Barang itu dimasukkan ke dalam lemari.' (Barang itu dimasukkan ke dalam lemari.)

35. Ladi haitu nialana dako riara nupeti. 'Pisau itu diambil dari dalam peti.' (Pisau itu diambilnya dari dalam lemari.)

\section{Simpulan}

Bentuk preposisi dalam BK terdiri atas dua macam yaitu preposisi tunggal dan preposisi gabungan. Preposisi tunggal terdiri atas preposisi kata dasar dan preposisi berfrefiks. Preposisi kata dasar dalam BK yaitu preposisi ri 'di' ri 'ke', dako ' dari', ante 'dan/ dengan' ante 'oleh', da 'sejak/semenjak', sampe 'hingga/sampai', $k a$ 'untuk', apa 'karena', dan saba 'sebab', dan preposisi berprefiks yaitu sagulili 'sekeliling', nosinggani 'bersama', risinjori 'sekitar', rikandate 'sepanjang', dan ane eva 'andaikata'. Preposisi gabungan terdiri atas preposisi berdampingan, preposisi berkorelasi, dan preposisi nomina lokatif. Preposisi berdampingan dalam BK yaitu sampe ri 'sampai ke', sampe ante 'sampai dengan', ntanina dako 'selain dari', nibasaka dako 'lepas dari'. Preposisi berkorelasi dalam BK yaitu ri antara... ante

'antara... dengan', daa... sampe nggapuri 'sejak...hingga sekarang', dako...hilau 'dari...ke', dako ...sampe 'sejak...hingga'. Preposisi nomina lokatif dalam BK yaitu ri ara 'di atas', ri bavo 'di atas', dan dako naira 'dari dalam'.

Fungsi preposisi kata dasar dalam BK yaitu menandai hubungan arah menuju suatu tempat, menyatakan tempat, menyatakan alat untuk atau dalam melakukan perbuatan atau tindakan yang dinyatakan oleh predikat klausa yang bersangkutan. Selain itu, juga berfungsi menyatakan pelaku perbuatan atau tindakan yang disebutkan dalam predikat klausa, menerangkan tentang lamanya waktu, menandai hubungan peruntukan, dan menandai hubungan sebab.

\section{Daftar Pustaka}

Alwi, Hasan. 2003. Tata Bahasa Baku Bahasa Indonesia. Jakarta: Balai Pustaka.

Chaer, Abdul. 1994. Tata Bahasa Praktis Bahasa Indonesia. Jakarta: Bharatara.

Char, Abdul. 2007. Linguistik Umum. Jakarta: Rineka Cipta.

Kaseng, Syahruddin. Et al. 1979. Bahasa-Bahasa Di Sulawesi Tengah. Jakarta: Pusat

Pembinaan dan Pengembangan Bahasa. Departemen Pendidikan dan Kebudayaan

Keraf, Gorys. 1984. Tata Bahasa Indonesia. Flores: Nusa Indah.

Pusat Pembinaan dan Pengembangan Bahasa Departemen Pendidikan Nasional Republik Indonesia. 2007. Pedoman Umum Ejaan Bahasa Indonesia Yang Disempurnakan. Bandung: Yrama Widya.

Samsuri. 1981. Analisa Bahasa. Jakarta : Erlangga. Sibarani, Robert. 1997. Sintaksis Bahasa Batak Toba. Medan: Universitas Sumatera Utara Press (USU PRESS).

Sudaryanto. 1993. Metode dan Aneka Teknik Analisis Bahasa. Yogyakarta: Duta Wacana Univesity Press.

Tarigan, H.G. 1984. Prinsip-Prinsip Dasar Sintaksis. Bandung: Angkasa. 